\title{
Suomalaisen kapitalismitutkimuksen ongelmia
}

\section{Jukka Gronow}

\section{Tutkimuksen taustaa}

Kun suomalainen valtiomonopolistista kapitalismia tutkiva projekti aloitti työnsä sen välittöminä esikuvina olivat ns. suuret vamokap-kirjat, neuvostoliittolainen Polititšeskaja ekonomija sovremennogo monopolistitšeskogo kapitalizma (saksaksi 1972), ddr:läinen Der Imperialismus der BRD (1972) ja ranskalainen Le Capitalisme monopoliste d'État (1971). Ulkomaisten tutkimusten innoittamana pyrittiin meilläkin kirjoittamaan suomalaisen kapitalismin valtiomonopolistista kehitysvaihetta koskeva tutkimus, jossa oli tarkoitus analysoida valtion laajenevan taloudellisen sääntelyn ja valtion ja monopolien voimien yhteenkietoutumisen merkitystä Suomessa. Lähes kymmenen vuotta myöhemmin ilmestynyt projektin lopputulos poikkeaa alkuperäisistä esikuvistaan monessa suhteessa ja sisältää varsin omaperäisen ja eräissä suhteissa ainutlaatuisen nykykapitalismin analyysin. ${ }^{1}$

Ehkä silmiinpistävin Suomalainen kapitalismi -teoksen piirre on kapitalismin nykytilanteen analyysin korostuminen. Tämä on ymmärrettävää jo ajallisesta perspektiivistä johtuen: marxilaista keskustelua hallitsee nykyisin kaikkialla kysymys nykyisestä kriisistä. Kriisianalyysi on kuitenkin myös yhteydessä tutkimuksen teoreettisen konseption kehittymiseen. 1960-luvulla kehittyneen marxilais-leniniläisen valtiomonopolistisen kapitalismin käsityksen taustalla oli kapitalismin sodanjälkeinen suhteellisen pitkä tasaisen kasvun kausi. Kapitalismin kriisitöntä kehitystä selitettiin niin tieteellis-teknisellä kumouksella kuin valtion kasvavalla talouden sääntelylläkin. Monopolien ja valtion voimien yhteenkietoutumisen katsottiin tehneen mahdolliseksi nopean tieteellis-teknisen kehityksen ja monopolipääoman arvonlisäyksen. Se tapahtui kuitenkin "kansan" kustannuksella. Tuloksena oli monopolien ja kansan välinen kärjistyvä ristiriita, joka muodosti monopolien vastaisen rintaman perustan.

Suomalainen kapitalismi -teoksessa ei keskustella erilaisista nykykapitalismia koskevista käsityksistä. Teoksen teoreettisissa osissa puhutaan monopolikapitalismista ja valtiomonopolistisesta kapitalismista, valtion ja monopolien voimien yhteenkietoutumisesta yms. Nämä käsitteet ovat kuitenkin teoksessa paremminkin eräänlaisia nykykapitalismin keskeisiä piirteitä kuvaavia ja yleistäviä käsitteitä kuin analyysin välineitä. Pekka Kosonen on aikaisemmissa tutkimuksissaan pyrkinyt kehittämään nykykapitalismin tutkimuksen teoreettis-metodisia lähtökohtia ja erityisesti ratkaisemaan ns. historisiteettiongelmaa eli kapitalismin uusien historiallisten kehityspiirteiden käsitteellistämisen ongelmaa. Kososen ratkaisu tähän ongelmaan - joka esitetään myös Suomalainen kapitalismi -teoksessa - on ollut kapitalismin uusien kehitysvaiheiden tarkastelu kapitalismin sisäisten lakien uusina ja samalla ristiriitaisina toteutumismuotoina- tai tapoina. ${ }^{2}$ Tämä ratkaisu on sisältänyt vaatimuksen niin monopolistisen arvonlisäyksen kuin valtion taloudellisen toiminnankin analysoimisesta pääoman arvonlisäyksen sisäisten ristiriitojen tuotteena. Keskeisiä pääoman sisäisten ristiriitojen ilmauksia ovat voiton suhdeluvun laskutendenssi ja pääoman liikakasautuminen: niin monopolipääoma kuin valtion taloudellinen toimintakin ymmärretään ratkaisuina voiton suhdeluvun laskutendenssin ja liikakasautumisen ongelmiin.

1. Pekka Kosonen ym.: Suomalainen kapitalismi. Tutkimus kapitalismin kehityksestä ja sen ristiriidoista sodanjälkeisessä Suomessa, Love Kirjat, Jyväskylä 1979.

2. Ks. Kosonen, Pekka: Kapitalistisen yhteiskuntamuodon teoriasta, Tutkijaliiton julkaisusarja 1, Helsinki 1976, s. 216-239 ja Kosonen, Pekka: Contemporary Capitalism and the Critique of Political Economy: Methodological Aspects, Acta Sosiologica vol. 20, 4/1977. 
Toinen suomalaisessa kapitalismitutkimuksessa korostunut ongelma on liittynyt konkreettisen tutkimuksen ja Marxin kapitalismiteorian suhteeseen. Tätä ongelmaa on ratkottu nojautuen Altvaterin ym. reaalianalyysiohjelmaan. ${ }^{3}$ Altvaterin ym. kasautumisanalyysin metodisena ongelmana on kapitalismin pinnan ja olemuskategorioiden välinen suhde, joka ratkaistaan ns. indikointimenetelmällä: hintasuureilla operoivilla pääoman kannattavųuden ja kokoonpanon mittareilla indikoidaan niitä vastaavien arvosuureiden kehitystä. Suomalainen kapitalismi-teos omaksuu tämän reaalianalyysin metodin omassa pääoman kannattavuuslaskelmassaan. Reaalianalyysia kritisoidaan kuitenkin siitä, että se on muutoin ymmärtänyt konkreettisen kapitalismitutkimuksen liian mekaanisesti. Konkreetin tutkimuksen tehtävänä on teoksen mukaan tutkia sitä, minkälaisia toteutumismuotoja kapitalismin yleiset lait saavat kussakin maassa ja historiallisessa kehitysvaiheessa, eikä yleisten lakien pätevyyden todistelu kussakin erityistilanteessa erikseen tai niiden mekaaninen soveltaminen kulloiseenkin tutkimuskohteeseen.

Suomalaisen pääoman tuotantoprosessin erityispiirteiden tutkiminen onkin eräs teoksen hallitseva piirre. Jopa siinä määrin, että monin paikoin on vaikea nähdä mitään kytkentää kapitalismin yleisten lakien ja ristiriitojen ja konkreettisen analyysin välillä. Tällöin konkreettinen analyysi jää usein abstraktiksi: yksityiskohtaiseksi ja seikkaperäiseksi ilmiöiden kuvailuksi ja viittauksiksi siihen, miten jotkin ilmiöt toteuttavat tuotannon tai pääoman uusia tarpeita. Näin on asianlaita varsinkin valtion taloudellista toimintaa ja työvoiman uusintamista koskevissa jaksoissa. Tämä johtuu paitsi konkreettisten ilmiöiden ja niiden johtamisen tai selittämisen kompleksisuudesta siitä, että suoritettu pääoman arvonlisäysprosessin ja sen ristiriitojen analyysi on ongelmallinen. Se ei tuota tulokseksi selväpiirteistä kä- sitystä suomalaisen pääoman arvonlisäysongelmista.

\section{Käsitys kriisistä}

Kapitalismin kriisin puhkeaminen 1970-luvulla on aktualisoinut marxilaisten tutkijoiden keskuudessa keskustelun kapitalismin ristiriidoista ja kriisin luonteesta. Keskustelu on tuonut samalla esille kriisiteorioiden ongelmat - voidaan jopa väittää että mitään kehittynyttä kriisikäsitystä ei toistaiseksi ole esitetty. ${ }^{4}$ Marxilaiset kriisikäsitykset voidaan jakaa karkeasti kolmeen ryhmään: liikakasautumiskonseptioon, realisaatio-ongelma- tai alikulutuskonseptioon ja tuotannonalojen tai tuontasektoreiden epätasaista kehitystä koskevaan konseptioon. ${ }^{5}$ Lisäksi tuotannon syklistä kehitystä selitetään kiinteän pääoman kierrolla. Suomalainen kapitalismi -teos mainitsee nämä kaikki erilaiset käsitykset, mutta ei ainakaan yleisellä tasolla keskustele niistä eikä niiden välisistä suhteista. Konkreettisessa analyysissään se painottaa eräänlaista realisointi- tai alikulutuskonseptiota. Tämä johtuu siitä, että suomalaisen pääoman arvonlisäysprosessin analyysi tuotaa tuloksen, jonka mukaan nykyinen kriisi Suomessa voidaan ymmärtää ensi sijassa realisointikriisiksi. Tulosten tulkinta on

3. Altvater, E. ym.: Entwicklungsphasen und -tendenzen des Kapitalismus in Westdeutschland (1. Teil). Probleme des Klassenkampfs 13, 2/1974. 4. Kosonen on eräässä toisessa yhteydessä todennut että "nähdäkseni marxilaisen kriisiselityksen kehittämisessä on vielä paljon työtä" (Överackumulationsdebatten och kapitalismens nuvarande kris. Nordisk Forum, nr 21, 33). Kososen mukaan ongelmana on ensinnäkin erilaisten kriisikonseptioiden - liikakasautumis- ja realisointikriisin - yhdistäminen ja toiseksi se, että konkreettinen kriisianalyysi on usein tyytynyt vain kuvailemaan erilaisia kriisitekijöitä. Tämä arvio pitää pitkälle paikkansa myös Suomalainen kapitalismi -teoksen kriisianalyysista.

5. Erilaisista kriisikonseptioista ks. esim. Beckenbach, F, Kräthe, M.: Zur Kritik der Uberakkumulationstheorie, Probleme des Klassenkampfs 30, $1 / 1978$ 
kuitenkin ongelmallista. Konkreettinen kriisianalyysi perustuu eräisiin pääoman kasautumista ja sen tutkimista koskeviin teoreettisiin ja metodisiin oletuksiin ja lähtökohtiin, jotka vaikuttavat analyysin suuntautumiseen ja tuloksiin.

Tarkastellessaan pääoman sisäisten lakien uusia historiallisia toteutumistapoja "Suomalainen kapitalismi" korostaa voiton suhdeluvun laskutendenssin lain merkitystä. Käsitys pääoman liikakasautumisesta kriisin syynä perustuu tähän lakiin, tarkemmin sanoen Marxin esittämään lain sisäisten ristiriitojen kehkeytymiseen. Suomalainen kapitalismi-teokseen sisältyy kuitenkin sellainen käsitys tuotantovoimien kehityksestä nykykapitalismissa, joka tekee tämän lain tulkinnan ja merkityksen problemaattiseksi.

Marx tarkastelee Pääoman kolmannessa kirjassa pääomar liikakasautumista eräänlaisen teoreettisen ääritapauksen, absoluuttisen liikakasautumisen muodossa. Absoluuttisesta liikakasautumisesta on kyse silloin, kun uusi, kasautunut pääoma ei enää lainkaan kasvata tuotetun lisäarvon määrää. Tällöin ei ainoastaan voiton suhdeluku, vaan myös voittomassa alenee tai säilyy korkeintaan entisen suuruisena. Tämä johtaa kasautumisen pysähtymiseen ja tuotannon supistumiseen. Kriisi ylitetään kun osa teollisuuspääomasta menettää arvonsa, mikä mahdollistaa jälleen kasautumisen jatkumisen, työn tuotantovoiman kasvun ja lisäarvon suhdeluvun kasvun.

Absoluuttinen liikakasautuminen on eräänlainen teoreettinen ääritapaus: sen edellytyksenä on, että uuden kasautuneen pääoman ei onnistu kasvattaa sen enempää absoluuttista kuin suhteellistakaan lisäarvoa. Sen enempää elävän työn määrää kuin työn tuotantovoimaakaan ei voida lisätä. Marxin tarkoituksena on tällaisen ääritapauksen avulla selvittää kriisimekanismin toimintaa, ei niinkään selittää tai johtaa kapitalismin periodittaisten kriisien välttämättömyyttä. Erilaisissa liikakasautu- misteorioissa onkin pyritty edelleen tulkitsemaan ja kehittämään Marxin tarkastelua. Grossmannin klassisessa "luhistumisteorissa" kasautumisen pysähtyminen perustuu siihen, että voiton suhdeluvun aleneminen tekee mahdottomaksi aikaisemman kasautumisasteen ylläpitämisen. Suhteellisen liikakasautumiseen perustuvissa käsityksissä taas voiton suhdeluvun alenemisen katsotaan sellaisenaan jossakin vaiheessa johtavan kasautumisen pysähtymiseen ja kriisiin. Yhteistä tällaisille käsityksille on se, että ne postuloivat jonkin tietyn voiton suhdeluvun tason, jonka ylläpitäminen on pääoman akkumulaatioprosessin jatkumisen ehto. ${ }^{6}$

Nämä ongelmat eivät kuitenkaan ole syynä siihen, että Suomalainen kapitalismi -teoksessa on luovuttu liikakasautumiskäsityksestä. Syyt ovat syvemmällä. Teoksessa asetetaan nimittäin varsin fundamentaalisella tasolla kyseenalaiseksi koko voiton suhdeluvun laskutendenssin lain käypyys nykykapitalismissa.

Voiton suhdeluvun laskutendenssin laki perustuu siihen, että lisäarvon suhdeluvun kasvu edellyttää työn tuotantovoiman kasvua. Tämä taas edellyttää Marxin mukaan pääoman elimellisen kokoonpanon (pysyvän ja vaihtelevan pääoman suhde) kasvua. Mihin tämä oletus perustuu? Perustuuko se tuotantovoimien kehityksestä viime vuosisadalla tehtyyn yleistykseen, vai onko elimellisen kokoonpanon kasvu jossakin vahvemmassa mielessä kapitalismia karakterisoiva välttämätön kehityspiirre? Tästä ongelmasta ei "Suomalainen kapitalismi" eksplisiittisesti keskustele. Sen sijaan teos edustaa sellaista käsitystä tuotantovoimien kehityksestä nykykapitalismissa, joka asettaa pääoman elimellisen kokoonpanon ja työn tuotantovoiman kasvun välisen yhteyden - ja siten voiton suhdeluvun laskutendenssin

6. Ks. esim. Krise und Kapitalismus bei Marx, Band I-II. Europeische Verlagsanstalt 1975, s. 431-433. 
lain - kyseenalaiseksi. Tämä käsitys tulee esille useassa eri yhteydessä.

Tarkastellessaan voiton suhdeluvun laskutendenssin lakia Marx esittää, miten sen toteutuminen riippuu joukosta ns. vastatendenssejä. Tarkastelumme kannalta kiinnostavin näistä vastatendensseistä on pysyvän pääoman elementtien arvon aleneminen, joka seuraa työn tuotantovoiman kasvusta - ja on siis tavallaan rinnakkainen lisäarvon suhdeluvun kasvulle. Jos pysyvän pääoman elementtien arvo alenee, kasvaa pääoman arvokokoonpano hitaammin kuin tekninen kokoonpano, ja tämä hidastaa voiton suhdeluvun alenemista. Suomalainen kapitalismi -teos puolestaan korostaa pääoman elementtien arvon alenemisen ohella pysyvän pääoman elementtien käytön tehostumista. ${ }^{7}$ Tämä vaikuttaa itse teknisen tai elimellisen kokoonpanon eikä ainoastaan arvokokoonpanon kehitykseen: työn tuotantovoiman kasvu ei tällöin välttämättä edellytä pääoman elimellisen kokoonpanon kasvua eikä myöskään johda voiton suhdeluvun alentumiseen. Tämän tekijän korostaminen on oireellista teoksen tuotantovoimahistoriakonseptiolle.

Tärkeämpää on kuitenkin, että Suomalainen kapitalismi -teokseen sisältyy implisiittinen käsitys kapitalismin tuotantovoimien kehityshistoriasta kolmivaiheisena prosessina. Ensimmäistä vaihetta luonnehtii tuotannon määrällinen laajeneminen ylimalkaan. Toista vaihetta, jota kutsutaan ekstensiivisen uusintamisen tyypiksi, luonnehtii työn tuotantovoiman ja pääoman teknisen kokoonpanon kasvu. Tällöin pysyvän pääoman materiaalisten elementtien määrä kasvaa nopeammin kuin tuotannon määrä. Kolmatta vaihetta kutsutaan intensiivisen uusintamisen tyypiksi ja sitä luonnehtii sekä työn tuotantovoiman kasvu että pysyvän pääoman elementtien tehostunut käyttö. Tällöin pysyvän pääoman materiaalisten elementtien määrä kasvaa hitaammin kuin tuotannon määrä. Nämä kolme vaihetta esitetään teok- sessa tosin vain eräänlaisena uusintamistyyppien ja uusintamisprosessin tutkimusta ohjaavana skeemana, johon ei sellaisenaan sisälly kapitalismin historiaa koskevia oletuksia. Suomalaisen pääoman uusintamisprosessien tarkastelut antavat kuitenkin ymmärtää, että kehittyneet kapitalistiset maat (ja erityisesti ns. pienet kehittyneet kapitalistiset maat) ovat siirtyneet kehityksessään kolmanteen, intensiivisen uusintamisen vaiheeseen. ${ }^{8}$ Tuotantovoimien kehitystä Suomessa verrataan jatkuvasti tähän oletettuun kehitykseen. Oletusta ei kuitenkaan ainakaan systemaattisesti perustella, vaan se esiintyy eräänlaisena implisiittisenä oletuksena tutkittaessa suomalaisen teollisuuden "pääomavaltaisuutta" tai "pääomien tehotonta hyväksikäyttöä".

Suomalaisen pääoman kriisikehityksestä esitetty tulkinta ei toki suoraan seuraa esitetystä uusintamistyyppihistoriasta, vaan uusintamistyyppejä ja arvonlisäysprosessia koskevasta konkreetista analyysista. Kuitenkin tuotantovoimahistoriakonseptio vaikuttaa itse tämän analyysin suoritustapaan, ja vain sen perusteella voidaan ymmärtää eräitä analyysin tuloksia.

7. On totta että Marx tarkastelee pysyvän pääoman elementtien käytön tehostumista Pääoman kolmannessa kirjassa - kuten "Suomalainen kapitalismi", toteaa (ks. s. 82) mutta ei kuitenkaan voiton suhdeluvun laskutendenssin lain ns. vastatendenssien yhteydessä. Tässä suhteessa teoksessa annetaan ehkä hieman liioiteltu kuva tämän tekijän merkityksestä Marxilla.

8. Vielä selvemmin tämä käsitys esiintyy eräissä Sakari Hännisen aikaisemmissa kirjoituksissa, joihin Suomalainen kapitalismi -teos näiltä osin paljolti perustuu (ks. esim. Hänninen, S.: Suomi pienenä valtiomonopolistisena maana, teoksessa Valtiomonopolistisen kapitalismin kriisi, SOTK:n tutkimusaineistoa 8, Tampere 1975 ja Hänninen, S.: Suomen tuotantorakenteesta, SOTK:n tutkimusaineistoa n:o 4. 


\section{Tuotantomuodon ja}

arvonlisäysmuodon analyysi

Suomalainen kapitalismi -teoksen keskeinen jakso - ainakin teoksen taloudellisia prosesseja koskevien tarkastelujen kannalta - on pääoman uusintamisprosessia koskeva luku. Tämä analyysi perustuu metodiseen innovaatioon, tuotanto- ja arvonlisäysmuodon erottamiseen ja erittelyyn. Nämä käsitteet määritellään eräänlaisiksi konkreettis-erityisen analyysin ja yleisemmän käsitteellisen analyysin välityskategorioiksi: "Tuotantomuoto vastaa tuotantovoimien konkreettis-erityistä toteutumismuotoa. Sitä määrittävät seuraavat rakenteelliset ja tekniset tekijät, kuten tuotantovoimien määrä ja laatu, tieteen ja tekniikan kehitystaso ja sovellutuskanta, tuotannon alarakenne (yhteiskunnallinen työnjako) ja työn tekninen organisaatio. Arvonlisäysmuoto vastaa tuotantosuhteiden konkreettis-erity istä toteutumismuotoa. Se viittaa niihin konkreettisiin voiton tuottamisen ehtoihin, joissa yksityinen kapitalisti kilpailun pakkolain alaisena toimii” (s. 120). Erottelua perustellaan työn kaksinaisluonteella: tuotantoprosessi on työja arvonlisäysprosessin ykseys. Sen tarpeellisuutta perustellaan myös TANDEM-kritiikillä: tekijöiden mukaan Demokratian rajat ja rakenteet -teoksessa on virheellisesti samaistettu nämä tasot ja tuotantomuotoa koskevista analyyseista on tehty välittömästi arvonlisäysehtoja koskevia johtopäätöksiä. ${ }^{9}$

Tuotantomuodon ja arvonlisäysmuodon erottelua noudattaen "Suomalainen kapitalismi" analysoi erikseen suomalaisen pääoman arvonlisäysehtoja (pääoman kannattavuuden kehitystä) ja tuotantovoimien kehitystä (käyttöarvojen tuotannon tehokkuutta tai uusintamistyypin kehitystä). Teoksen tärkein, uusi empiirinen tulos perustuu kannattavuuslaskelmaan, jossa Altvaterin ym. kehittämää kannattavuuden (tai rentabiliteetin) mittaria on sovellettu Suomen teollisuuteen. (Tällaisiin mittauksiin sisältyy luonnollisesti monia ongelmia - kuten teoksessakin todetaan - mutta yleisesti ottaen suoritettu laskelma on paras mahdollinen käytettävissä olevat tilastot huomioonottaen.)

Tämän kannattavuuslaskelman keskeiset tulokset ovat seuraavat:

1. Pääoman kannattavuus on kasvanut Suomessa 1960-luvulla ja 70-luvun alussa. Kannattavuus kääntyy jyrkkään laskuun vasta kriisin puhjetessa 70-luvun puolivälissä. Kannattavuuden kehitys poikkeaa esim. SLT:n kehityksestä: Saksan liittotasavallassa kannattavuus kääntyy laskuun jo 1960-luvulla.

2. Pääoman elimellinen kokoonpano on teollisuudessa korkea, mutta se on alentunut hieman tarkasteluajanjakson kuluessa.

3. Liikkuvan pääoman kierrosaika on pitkä, mutta se on alentunut jonkin verran.

4. Lisäarvon suhdeluku on kansainvälisesti katsoen alhainen. Kannattavuuden paraneminen johtuu kuitenkin ensi sijassa lisäarvon suhdeluvun suhteellisen nopeasta kasvusta. Tämän taas on tulkittu johtuvan kolmesta tekijästä: palkkojen kasvun hitaudesta, työn voimaperäistämisestä ja - ennen kaikkea - vientihintojen suotuisasta kehityksestä. Viimeksimainittua taas selitetään $\mathrm{mm}$. keskeisten vientiteollisuuden alojen monopolihinnoilla.

Kriisitarkastelun kannalta kannattavuusanalyysin tulokset ovat mielenkiintoisia: 70-luvun puolivälissä puhjennutta kriisiä ei ole Suomessa pohjustanut pääoman arvonlisäysehtojen huononeminen - päinvastoin kuin eräissä muissa kehittyneissä kapitalistisissa maissa. Suomessa kannattavuuden heikkeneminen johtuu maailmamarkkinakriisin puhkeamisesta ja vientituotteiden kysynnän heikkenemisestä. Suomalainen kriisi näyttää olevan tuontitavaraa, eikä sitä selitä esim. kotimaisen pääoman liikakasautuminen.

9. Ks. myös Hänninen, S./Kosonen, P.: Talouden rakennetekijät ja kriisi, Tiede ja edistys $2 / 1978$. 
Pääoman uusintamisprosessin tutkimuksen toisen puolen - tuotantomuodon analyysin tulkinta on huomattavasti vaikeampaa, sillä se sisältää useita erilaisia ja eritasoisia tarkasteluja. Ensi lukemalta näyttää siltä, että tuotantomuodon analyysi rajoittuisi vain lyhyehköön jaksoon, jossa sangen ylimalkaisesti luonnehditaan eräitä tuotantovoimien ja työnjaon kehityspiirteitä Suomessa (ks. s. 122-137). Kuitenkin koko uusintamisprosessi-luvun alku, joka edeltää tuoantomuodon ja arvonlisäysmuodon käsitteellistä erottelua, on tulkittava tuotantomuodon - tuotantovoimien konkreettis-erityisen toteutumismuodon - tutkimukseksi. Kasautumis- ja investointiaste- sekä uusintamistyyppi-analyyseissa on kaikissa kyse "pääoman käytön tehokkuudesta" tai paremminkin käyttöarvojen tuotannon tehokkuudesta, jota tutkitaan erilaisten osoittimien avulla. Näistä laskelmista saatu yleinen tulos on pääomien käytön suhteellinen tehottomuus Suomessa. Suomalaista tuotantoprosessia luonnehtii "pääomia sitova kehitystyyppi" (ks. s. 111). Vaikka tuotannon kasvu on kansainvälisesti katsoen ollut suhteellisen nopeaa, se on vaatinut suuria (pysyvän tai kiinteän) pääoman investointeja. Pysyvän tai kiinteän pääoman elementtien määrä on kasvanut nopeammin kuin tuotettujen tuotteiden määrä. Eri laskelmat tuottavat kuitenkin hieman erilaisia tuloksia. Tuottavan kasautumisen (tai investointi-) asteen todetaan olevan erityisen korkea. Teollisuuden todetaan kuitenkin toisaalta sijoittuvan uusintamistyyppien eräänlaiseksi rajatapaukseksi: vaikka pääomaintensiteetti on kasvanut, on myös pääomakerroin kasvanut (ekstensiivinen ja intensiivinen uusintamistyyppi "'operationalisoidaan" näiden osoittimien avulla). Tuotannonaloja koskevat panos-tuotos laskelmat osoittavat eräiden keskeisten alojen olevan pääomavaltaisia ja jalostusasteeltaan alhaisia jne. Osin laskelmat näyttävät koskevat "pääomavaltaisuuden" tasoa, osin sen kehitystä. Ongelmallista on myös se, että näitä tuloksia ei lainkaan suhteuteta arvonlisäysmuodon analyysin tuloksiin, jotka osoittavat pääoman elimellisen kokoonpanon ja pääoman kierrosajan pienentyneen. Tämä liittyy kuitenkin jo yleisempään ongelmaan: tuotantomuodon ja arvonlisäysmuodon analyysien suhteeseen.

Tulosten hajanaisuus ja niiden tulkinnan vaikeus on hyvin ymmärrettävää. Käyttöarvojen tuotannon tehokkuutta koskevat laskelmat ovat varsin ongelmallisia. Erilaisia tehokkuusindikaattoreita käytettäessä joudutaan hintasuureisiin perustuvien laskelmien perusteella tekemään johtopäätöksiä, jotka koskevat pääoman eri osien materiaalisten elementtien ja tuotannon määrällisiä mutoksia. Näiden indikaattorien käyttöä ja tulosten tulkintaa ei teoksessa lainkaan problematisoida (ilmeisesti on kuitenkin niin, että vaikka tuotantomuodon tasoon kuuluvista osoittimista ei saa tehdä johtopäätöksiä jotka koskevat arvonlisäysmuodon kehitystä (ks. s. 128), päinvastainen menettely on mahdollista). Vaikka periaatteessa hyväksyttäisiinkin tällaisten tehokkuuslaskelmien käyttö, käytettyjä indikaattoreita voi pitää varsin puutteellisina. Lähes kaikki osoittimet ottavat huomioon vain pääomakannan (kiinteän pääoman) muutokset siten niiden perusteella ei voi tehdä mitään johtopäätöksiä, jotka koskevat koko pysyvän pääoman elementtien käytön tehokkuutta. Tämä tulosten tulkinnan ongelma myönnetään teoksessa eräässä kohdin: tulokset voivat heijastaa yhtä hyvin muutoksia kapasiteetin käyttöasteessa, pysyvän pääoman kierrosajassa kuin pysyvän pääoman elementtien käytön tehostumistakin (ks. s. 117-118). On siten varsin järkevää, että tuloksia ei ole käytetty pääoman arvonlisäysprosessin tulkinnassa, eikä esimerkiksi pääoman elimellisen kokoonpanon kehityksen tarkastelua ole liitetty käyttöarvojen tuotannon tehokkuutta koskeviin tarkasteluihin. Tuotantomuodon ja arvonlisäysmuodon erottamismetodin hedelmällisyyden tämä analyysi kuiten- 
kin asettaa kyseenalaiseksi: käytännössä tuotantomuodon ja arvonlisäysmuodon erottelu on absolutisoitu eikä niiden "vuorovaikutusta" tarkastella ainakaan systemaattisesti. Vain hieman yksinkertaistaen voisi uusintamisprosessin analyysin tuloksen tiivistää suomalaisen kapitalismin "'kaksinaisluonteeksi": voittojen tuotanto on liian tehokasta, käyttöarvojen liian tehotonta.

Tuotantomuototarkastelu ei kuitenkaan jää vain - sinänsä mielenkiintoiseksi, mutta jokseenkin hedelmättömäksi - metodiseksi kokeiluksi. Siitä tehdään nimittäin johtopäätöksiä ohitse arvonlisäysmuodon tarkastelun - jotka koskevat mm. työväenluokan asemaa, kulutuskysyntää, kriisiä ja valtiointerventiota. Kaikki nämä johtopäätökset tiivistyvät erityiseen alikulutuskonseptioon, joka perustuu pääoman kasautumista koskeviin laskelmiin.

Realisointi- tai alikulutusteoriat kriisin selittäjinä perustuvat yleensä Marxin "Lisäarvoteorioissa" esittämiin kriisitarkasteluihin. Marxin mukaan on helppo ymmärtää miksi eri tuotantoalojen kehitys kapitalismissa on epätasaista ja miksi eri aloilla voi esiintyä ylituotantoa. Tuottaja voi vasta tuotuaan tuotteensa markkinoille havaita, onko hänen tuotteensa tyydyttänyt jonkin yhteiskunnallisen, maksukykyisen tarpeen. Yksittäisillä tuotantoaloilla esiintyvä ylituotannon mahdollisuus on kuitenkin eri asia kuin yleinen tavaroiden ylituotanto, joka johtaa kriisiin. Yleisen ylituotannon abstrakti mahdollisuus sisältyy Marxin mukaan jo tavaran metamorfoosiin, käyttöarvon ja vaihtoarvon ja edelleen tavaran ja rahan väliseen ristiriitaan. Tavaraa ei vaihdeta toiseen tavaraan vaan rahaan: tavaran myyntiä ei siten välttämättä seuraa toisen ostaminen. Tämä tavaran metamorfoosiin sisältyvä kriisin mahdollisuus on kuitenkin vain sen "'abstraktein muoto"10. Liikatuotannon erityisenä ehtona onkin Marxin mukaan "tuottavan pääoman yleinen laki’': ',tuottaa tuotantovoimien asettamaan rajaan saakka, eli riistää annetulla pääomamäärällä maksimimäärä työtä ottamatta lainkaan huomioon markkinoiden todellisia rajoja tai tarpeita, jotka perustuvat kykyyn maksaa: ja tämä tapahtuu jatkuvan tulon (revenuen) pääomaksi muuttumisen kautta, kun taas toisaalta tuottajien massa jää sidotuksi määrättyjen tarpeiden tasoon, ja sen täytyy jäädä sidotuksi tarpeiden tasoon kapitalistisen tuotannon luonteen mukaisesti.' 11

Pääoman ja palkkatyöläisen välisestä lisäarvon anastussuhteesta on seurauksena, että suurin osa "tuottajista" (työläiset) ei kuluta kuin pienen osan tuottamastaan tuotteesta. Työläiset ovat tässä mielessä aina liikatuottajia.

"Lisäarvoteorioiden" ylituotantotarkasteluihin näyttää sisältyvän kaksi erillistä argumenttia. Toisaalta Marx toteaa tavaratuotantoon aina sisältyvän ylituotannon- ja kriisin mahdollisuuden: osto ja myynti ovat eri tapahtumia ja lisäarvon tuotannon ja realisoinnin ehdot ovat kaksi eri asiaa. Tässä on kuitenkin kyse vain kriisin abstraktista mahdollisuudesta tai muodosta. Toisaalta Marx näyttää omaksuneen jo Marxia edeltäneessä poliittisessa taloustieteessä esiintyneen alikulutuskäsityksen, jonka mukaan työläiset ovat aina "ylituottajia", koska he eivät voi koskaan kuluttaa tuottamaansa tuotetta kokonaan. He ovat lisätuotteen eli lisäarvon tuottajia. Jälkimmäinen käsitys ei esiinny enää Pääomassa. Marx näyttää siten luopuvan klassisesta alikulutuskonseptiosta alkaessaan kehittää omaa pääoman liikakasaantumisteoriaansa.

Klassinen alikulutuskonseptio onkin ongelmallinen Marxin kehittyneen poliittisen taloustieteen kritiikin kannalta: se ei ota huomioon sitä, että myös kapitalistit ovat kuluttajia ja että myös tuottava kulutus - tuotantovälineiden ostaminen ja käyttö - on kulutusta. Eräs mahdollisuus on yhdistää alikulutuskon-

10. Marx-Engels Werke 26. 2., 539.

11. Marx-Engels Werke 26. 2., 535. 
septio yleiseen kasautumislakiin, jonka mukaan pääoma syrjäyttää jatkuvasti tuotannosta elävää työtä - ja synnyttää suhteellista liikaväestöä - ja samalla pienentää sekä palkkojen osuutta että työvoiman hintaa. Tämä pyrkii vähentämään varsinaista kulutuskysyntää ja vaikeuttamaan kulutustavaroiden realisointia. Tällainen käsitys on kuitenkin jo varsin lähellä tuotannonalojen epätasaista kehitystä koskevia teorioita.

Liikakasautumis- ja realisointi- tai alikulutusteorioiden yhdistäminen - johon aikaisemmin viitattiin - on varsin ongelmallista. Vaikka liikakasautuminen ilmenee aina myös ylituotantona, ja vaikka realisointiongelma samalla merkitsee sitä, että pääomia on - suhteessa maksukykyiseen kysyntään - liikaa, ovat näiden teorioiden esittämät liikakasaantumis- ja ylituotantoehdot vastakkaisia. Liikakasautumiskäsityksen mukaan ylituotanto johtuu siitä, että lisäarvon määrä ja voiton suhdeluku alenevat. Realisointiongelmaa painottava käsitys taas korostaa sitä, että ylituotantoa voi esiintyä silloinkin, kun lisäarvon- ja voiton tuotannon edellytykset ovat hyvät: kriisiä ei siten edellä voiton suhdeluvun aleneminen, vaan kulutuskysynnän heikkeneminen.

Suomalainen kapitalismi-teoksen käsitys pääoman kriisistä perustuu eräänlaiseen alikulutusteoriaan. Suomen talouden kriisi selitetään sekä kotimaisen kulutuskysynnän että ulkomaisen, vientituotteisiin kohdistuvan kysynnän pienenemisellä. Maailmantalouden kriisin analyysi liittyy suomalaisen pääoman kannattavuuslaskelman tuloksiin. Sen keskeinen tuloshan on, että kannattavuuden jyrkkä lasku 1970-luvun puolivälissä johtuu vientituotteiden kysynnän heikkenemisestä. Tämä selitetään maailmantalouden kriisillä, joka kuvataan useiden tekijöiden yhteisvaikutuksen tulokseksi (pääomien nopea kasaaminen 60-luvulla, inflaatio, joka pienentää kulutusta, ja raaka-aineiden ja energian hinnannousu, ks. s. 222-223). Olennaista tässä tarkastelussa on se, että kriisiä edeltänyt kehitys on johtanut tilanteeseen, jossa pääomia on liikaa suhteessa kulutuskysyntään. Jostain syystä tilanteen katsotaan kaiken lisäksi merkitsevän käännekohtaa kapitalismin kehityksessä: puhutaan kroonisten kriisi-ilmiöiden lisääntyvästä merkityksestä ja kapitalismin taloudellisen perustan kriisistä. Toisaalta kulutuskysynnän supistuminen kotimaassa on samanaikaisesti voimistanut kriisiä. Laman oloissa harjoitettu talouspolitiikka on edelleen rajoittanut kysyntää ja ylläpitänyt lamaa.

"Suomalaisen kapitalismin" omaperäinen käsitys kriisistä perustuu kuitenkin varsinaisesti krooniseen kulutuskysynnän supistumiseen Suomessa. Tämä johdetaan tuotantomuodon analyysista, tarkemmin sanoen "kasautumistekijän" tärkeydestä Suomen teollisuudessa: "Tämän voimakkaan kasaamisen kääntöpuolena on luonnollisesti ollut kulutuksen supistaminen, joka on kohdistunut työtätekevien elintasoon" (s. 111). Edelleen todetaan, että "Suomen taloudelle ominaisesta kasaamisen kiihkeydestä ja sen suhteellisen suuresta keskittymisestä puunjalostusteollisuuteen ei sinänsä voi tehdä kovin pitkälle meneviä johtopäätöksiä. Vaikka tämä supistaa kulutuksen osuutta, kulutuksen absoluuttinen taso samoin kuin palkkataso riippuvat paljolti tuotannon tuloksesta" (s. 114-115). Olennaista siis on, että voimakas kasaaminen on supistanut kulutuksen osuutta.

Tämä väite ei tilanteen kuvauksena pidä paikkaansa. Sen perusteluksi esitetyt laskelmat eivät nimittäin lainkaan kuvaa lisäarvon tai palkkojen osuutta tai edes voittosuhdetta. $\mathrm{Ne}$ osoittavat lähinnä vain sen, että kiinteän pääoman investoinnit ovat olleet suhteellisen suuria. Kaiken lisäksi rentabiliteettilaskelmat - arvonlisäysmuodon analyysi - osoittaa, että sekä lisäarvon suhdeluku että voittosuhde ovat Suomessa suhteellisen alhaisia. Jos tuotantonmuodon analyysista - käyttöarvojen tuotannon tehokkuudesta - joitain johtopää- 
töksiä kulutuksen suhteen voidaan tehdä, ne koskevat nimenomaan kulutuksen tasoa, eivätkä sen osuutta.

Toiseksi alikulutusselitys perustuu nurinkuriseen argumentaatioon. Vaikuttaa siltä kuin tekijät ajattelisivat kasaamis- tai investointitarpeen säätelevän lisäarvon tuotantoa, eikä päinvastoin. Kuitenkin teoksessa kritisoidaan Samuelsonia tällaisesta käsityksestä: kapitalistisessa tavaratuotannossa ei ole mitään instanssia, joka päättäisi miten tuotannontekijät ja tuotannon tulokset jaetaan (ks. s. 80).

\section{Käsitys valtion}

\section{taloudellisesta toiminnasta}

Voimakkaan kasaamisen kääntöpuoli, krooninen alikulutus, selittää myös valtion taloudellista toimintaa ja pääoman uusintamisongelmia Suomessa. Valtion taloudellisen toiminnan tarkastelu jakautuu kahteen osaan, joissa tarkastellaan ensiksi talouspolitiikan kehitystä toisen maailmansodan jälkeen ja toiseksi niitä mekanismeja, joilla valtio edistää arvonlisäystä Suomessa. Talouspolitiikan tutkimuksen keskeinen käsite on "perinteinen talouspolitiikka", jota "on . . kuvattu linjaksi, jossa katsotaan investointien vaativan suurta säästämistä ja jossa erityisesti vientiyritysten rahoitus ja muu tukeminen on etusijalla... Näihin tekijöihin liittyy se, että investointiaste on ollut poikkeuksellisen korkea, siis suuri osa tuloista on mennyt tällaiseen pääoman kasaamiseen. Tästä on seurannut tulonjako-ongelma, kysymys siitä kuinka suuri osa tulonmuodostuksesta kyetään kanavoimaan investointeihin palkkojen ja kulutuksen kustannuksella" (s. 161-162). "Jotta rahaa olisi riittänyt investointeihin tästä on seurannut tavoitteena palkkojen ja kulutuksen sääntely" (162).

"Perinteisen talouspolitikan" käsite kuvaa varmasti osuvasti erästä hallitsevaa talouspoliittista doktriinia Suomessa. Palkkojen sääntelyä on perusteltu kansantalouden ja teollisuuden suurella investointitarpeella (ja legiti- moitu sillä että 'tämän päivän voitot - tai investoinnit - ovat huomispäivän palkankorotuksia"). Tällaisella käsityksellä on oikeutuksensa. Kaikkein abstrakteimmalla tasolla voidaankin valtion talouspolitiikassa aina ajatella olevan kyse voittojen ja palkkojen sääntelystä. Lisäksi ei voitane kiistää, etteikö tulonjakokysymys olisi ollut suomalaisen talouspolitiikan ydinkysymys tai etteikö "keynesiläisen" suhdannesääntelyn puuttuminen luonnehtisi harjoitettua talouspolitiikkaa. Suomalainen kapitalismi -teos pyrkii kuitenkin korostamalla kasautumistekijän tärkeyttä tavoittamaan joitakin suomalaisen taloussääntelyn erityisiä ongelmia ja vahvassa mielessä johtamaan siitä valtion taloudellisen toiminnan suomalaisia erityispiirteitä.

Suomalainen kapitalismi -teoksessa viitataan myös toiseen rinnakkaiseen selitykseen, joka korostaa tulonjakokysymyksen keskeisyyttä taloudellisessa sääntelyssä: suomalaisen pääoman asemaan kansainvälisessä kilpailussa ja palkkakustannusten merkitykseen heikon tuottavuuden kompensoijana. Tämä selitys jää kuitenkin ongelmalliseksi, koska Suomen asemaa kansainvälisessä taloudessa analysoivassa luvussa keskitytään tuonnin ja viennin rakenteen ja tuotannon suhteellisen tehottomuuden (vrt. tuotantomuotoanalyysi) selvittämiseen. Kilpailun modifioitumista maailmanmarkkinoilla ja pääoman kansainvälisiä arvonlisäysehtoja ei oikeastaan tutkita. ${ }^{12}$ Tätä ongelmaa korostaa vielä se, että kansainvälistä taloutta eritellään vasta sen jälkeen, kun on tarkasteltu kriisiä, valtion taloudellista toimintaa jne.

Valtion taloudellista toimintaa koskeva luku jää kaiken kaikkiaan varsin kuvailevaksi ja aineistokeskeiseksi. Sen toisen osan jäsentely

12. Pekka Kosonen on kuitenkin aikaisemmin tutkinut kansainvälistä kilpailua, ks. Valuuttakurssimekanismi ja maailmanmarkkinat, TANDEMin tutkimusraportti n:o 10, Helsinki 1976. 
on tässä suhteessa kuvaava. Siinä pyritään selvittämään niitä mekanismeja, joiden kautta valtio puuttuu pääoman arvonlisäykseen. Niinpä se sisältääkin varsin yksityiskohtaisen ja laajan kuvauksen "rahavirtojen" ohjaamisesta (rahoitusjärjestelmä ja rahoituspolitiik$\mathbf{k a}$, yritysverotus ja valtiolliset investoinnit ja omistus). Sen sijaan valtion taloudellisen toiminnan uudet muodot ja määrällinen kasvu jäävät paljolti selittämättä. Erityisen selvästi tämä ongelma tulee esille ns. rakennepolitiikan kohdalla: valtionyhtiöt ovat varmasti olleet tärkeitä teollisuuden rakenteen monipuolistajia - kuten teoksessa todetaan - mutta miksi perinteinen tuotantorakenne on muodostunut ongelmaksi, johon valtion on puututtava?

Tarkastelut, jotka koskevat valtion puuttumista pääoman uusintamiseen, jäävät kuvaileviksi aivan ilmeisesti siksi, että pääoman uusintamisprosessin ristiriitojen analysointi ei ole tuottanut sellaisia tuloksia, joihin valtiollisen sääntelyn erittely voisi nojautua. Suomalaisen pääoman arvonlisäyksen voi teoksen tulosten valossa oikeastaan todeta olleen varsin ongelmatonta ja ristiriidatonta toisen maailmansodan jälkeen - sen ainoana ongelmana on ollut käyttöarvojen tuotannon tehottomuus. Tämä taas ei ole vielä sinänsä ongelma pääoman kannalta, vaan ainoastaan kapitalismin tutkijoiden kannalta.

Vielä ongelmallisempi tässä suhteessa on työvoiman uusintamista koskeva teoksen jakso. Siinä esitetään varsin seikkaperäisiä kuvauksia sosiaalipolitiikan ja työvoimapolitiikan kehityksestä sekä työvoiman uusintamisehdoista. Uusintamisehtojen muuttumista ja uusien "tarpeiden" syntyä selitetään yleensä vain viittaamalla abstraktisti tuotannon tai työväenluokan uusiin vaatimuksiin.

',Suomalainen kapitalismi"'

kapitalismin kokonaisesityksenä

"Suomalainen kapitalismi" päätyy Suomen poliittista tilannetta arvioidessaan samanlai- seen tulokseen kuin TANDEMin "Demokratian rajat ja rakenteet" paria vuotta aikaisemmin: " . . . integrointipolitiikka näyttää onnistuneen paremmin kuin monessa muussa kapitalistisessa maassa. Välitöntä uhkaa luokkavallan uusintamiselle ei ole syntynyt. Katsomme siis, että hallitsemistavan kehitystä tarkasteltaessa Suomessa ei voi puhua varsinaisesta poliittisesta kriisistä"' (s. 440). "Suomalainen kapitalismi" ei sen enempää kuin TANDEMin loppuraporttikaan selvitä sitä miten ja miksi tämä integraatio on onnistunut. Sen kapitalismitutkimus on tässä suhteessa yhtä lailla rajoittunutta. Se keskittyy analysoimaan taloudellisia kehitysprosesseja ja poliittisen järjestelmän kehitystä. Vaikka tällainen rajaus on tutkimusteknisesti legitiimi, se antaa aiheen korostaa eräitä nykykapitalismin tutkimuksen ajankohtaisia ongelmia. Teos itse esittää tämän ongelman keskustellessaan demokraattisen hallitustyypin edellytyksistä seuraavasti: "Tällaisen laajan rintaman objektiiviset edellytykset ovat kyllä sikäli olemassa, että ... monien työtätekevien ryhmien edut ovat samansuuntaiset. Sen sijaan subjektiiviset edellytykset, niin työtätekevien keskuudessa kuin heitä edustavien järjestöjen johdon keskuudessa ovat huonommat" (s. 484). Tämän kysymyksen voisi tiivistää reformismin tutkimuksen ongelmaksi.

Yleisellä tasolla "'Suomalainen kapitalismi", viittaa tähän ongelmaan mm. todetessaan, että "toisaalta talouspolitiikkaa ja taloudellista sääntelyä ei koskaan saa johtaa mekaanisesti pääoman uusintamisehdoista, ikäänkuin valtio vain täyttäisi pääomapiirien vaatimuksia. Kyse on aina myös poliittisista ratkaisuista . . ." (s. 161). Vaikka tämä ohjelmallinen vaatimus on hieman onnettomasti muotoiltu ${ }^{13}$, siihen sisältyy periaatteessa oikea ajatus. Pääoman arvonlisäysongelmien ja valtion taloussääntelyn tutkimisen ohella pitäisi tutkia sitä, miten pääoman arvonlisäysristiriidat - ja työvoiman uusintamisongelmat - välittyvät poliittisiksi 
ongelmiksi ja ratkaisuiksi. Suomalainen kapitalismi -teoksessa vaatimus jää vain ohjelmalliseksi. Vaikka se useassa kohdin - etenkin työvoiman uusintamista koskevassa luvussa viittaa siihen, miten valtion toimenpiteet ovat poliittisen taistelun tuloksia, ei poliittista välitystä kuitenkaan tutkita. Tällainen tutkimus on välttämätön reformismin kritiikin osa.

Arvonlisäysvaatimusten välittyminen (laajasti ymmärretyksi) talouspolitiikaksi on kuitenkin vain eräs puoli reformismikritiikistä. Suomalainen kapitalismi -teoksen kokonaisvaltainen tutkimus pyrkii hahmottamaan myös ongelman toista puolta - palkkatyöläisten tietoisuuden ongelmana - mutta tässä suhteessa teoksen anti on ehkä kaikkein ohuin. Jaksossa "Piirteitä ideologisesta kehityksestä ja aatteiden taistelusta" tarkastellaan lähinnä kahden ideologisen instituution, koululaitoksen ja joukkotiedotuksen kehitystä itsenäisessä Suomessa ja se painottuu ideologiaa tuottavien apparaattien käsittelyyn. Luvun alussa tosin mainitaan myös objektiivisten - yhteiskunnallisten suhteiden tuottamien - ajatusmuotojen merkitys yhteiskunnan tajunnallisessa uusintamisessa, mutta varsinaisesti tätä ongelmaa ei tutkita, eikä myöskään problematisoida riittävästi.

Tämä puute on hyvin ymmärrettävä. Kyse on ongelmista, joita marxilainen tutkimus on vasta hahmottamassa ja etsimässä niiden tutkimisen ohjelmallista lähtökohtaa. Lähivuosina kapitalismin arkipäivän ja palkkatyöläisen sosialisaatioprosessin ongelmat tulevat varmasti korostumaan niin marxilaisessa tutkimuksessa kuin yhteiskunnallisina ongelminakin. Tämä ei merkitse sitä, etteikö "Suomalaisen kapitalismin" vahvin puoli, kapitalismin taloudellisten prosessien analyysi tule lähivuosinakin säilymään keskeisenä kapitalismitutkimuksen kohteena. Ja tässä suhteessa teos edustaa tärkeää kapitalismitutkimuksen "välitilinpäätöstä”.

13. Pääomapiirien vaatimukset ovat nimittäin eri asia kuin "pääoman vaatimukset" ja on jo sinänsä ongelma miten "pääoman vaatimukset" välittyvät "pääomapiirien vaatimuksiksi".

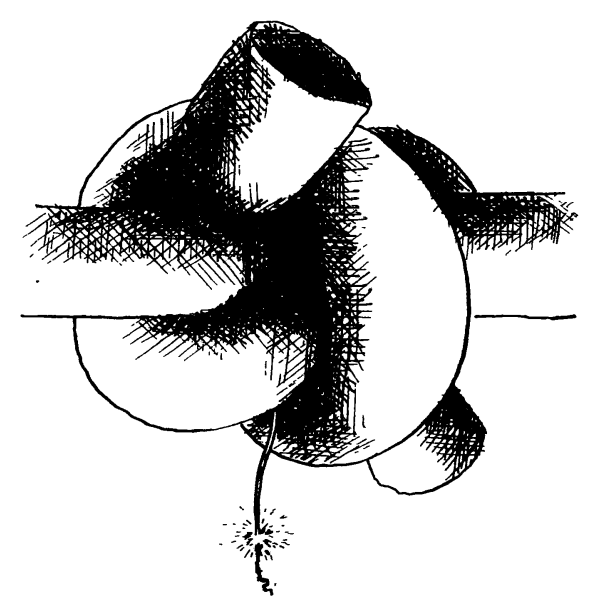

\section{"'Tiede, sivistyneistö, työväenluokka''-kirja}

- Pohdintaa: Demokraattinen ammattikäytäntö tie ulos opiskelijaliikkeen kriisistä? 70-luvun merkkipaalut - 80-luvun näköalat. Opiskelijaliike, korkeakoulupolitiikka, yliopisto. Teesejä tutkinnonuudistuksesta Saksan Liittotasavallassa. Yliopistostrategiamme tänään? Näkökohtia teemaan "porvarillisen tieteen kritiikki'”. Teoria, käytäntö, poliittinen tietoisuus. Onko marxilaisuus vaihtoehto ja miten sitä opiskellaan?

- Pohdiskelijat: Keijo Ahola, Christine Becker, Seppo Kähkönen, Pekka Kämäräinen, Heikki Mäkikulmala, Ville Ovaskainen, Kari Piippo, Seppo Raiski, Matti Reinikainen, Seppo Toiviainen. Kirjan toimittanut: Matti Vartiainen.

- Kirja sisältää SOL:n 12. liittokokouksen tärkeää keskustelua, josta osa julkaistaan Soihdussa ja Soihdunkantajassa. Ilmestyy joulukuussa.

- Tilaa ja osta! Hinta 20 markkaa, 152 sivua. Tilaa osoitteella: SOL, III linja 7 B 37, 00530 Hki 53. Puh. 90-736 112. Maksu ps-tilille 789 12-0. 